\title{
Spatial Analysis of Environmental Noise and Auditory Health of Abeokuta Residents, Ogun State, Nigeria
}

\author{
1*OGUNTOKE, O; ${ }^{1}$ TIJANI, YA; ${ }^{2}$ ADETUNJI, OR; ${ }^{3}$ OBAYAGBONA, ON \\ ${ }^{I}$ Department of Environmental Management and Toxicology, ${ }^{2}$ Department of Mechanical Engineering, Federal University of Agriculture, \\ Abeokuta PMB 2240, Ogun State, Nigeria \\ ${ }^{3}$ Department of Environmental Management and Toxicology, University of Benin, Benin City, Edo State, Nigeria \\ "Corresponding Author Email: Omoregbe.obayagbona@uniben.edu
}

\begin{abstract}
This study assessed environmental noise levels, mapped the spatial pattern at different times of the day and examined the association with morbidity of auditory ailments in Abeokuta metropolis. The entire metropolis was divided into 80 cells (areas) of $1000 \mathrm{~m}^{2}$; out of which 33 were randomly selected for noise levels assessment. Portable noise meter (AR824) was used to measure noise level and Global Positioning System (Garmin GPS-72H) was employed to take the coordinates of the sample sites for mapping. Risk map of the noise levels were produced using Kriging interpolation techniques based on the spatial spread of measured noise values across the study area. Data on cases of hearing impairments were collected from four major hospitals in the city. Data collected from field measurements and medical records were subjected to descriptive (frequency and percentage) and inferential (Mean, ANOVA and correlation) statistics using SPSS (version 20.0). ArcMap 10.1 was employed for spatial analysis and mapping. Results showed mean noise levels range at morning $(42.4 \pm 4.14-88.2 \pm 15.1 \mathrm{dBA})$, afternoon $(45.0 \pm 6.72-86.4 \pm 12.5 \mathrm{dBA})$ and evening $(51.0 \pm 6.55-84.4 \pm 5.19 \mathrm{dBA})$ across the study area. The interpolated maps identified Kuto, Okelowo, Isale-Igbein and Sapon as high noise risk areas. The monitored noise levels varied significantly among the sampled areas at morning, afternoon and evening $(p<0.05)$. Significant correlation was found between diagnosed cases of auditory ailments and noise levels measured in the morning $(\mathrm{r}=0.39$ at $p<0.05)$. Common auditory ailments found across the metropolis included impaired hearing $(25.8 \%)$, tinnitus $(16.4 \%)$ and otitis $(15.0 \%)$ respectively.
\end{abstract}

\section{DOI: https://dx.doi.org/10.4314/jasem.v23i9.15}

Copyright: Copyright $(02019$ Oguntoke et al. This is an open access article distributed under the Creative Commons Attribution License (CCL), which permits unrestricted use, distribution, and reproduction in any medium, provided the original work is properly cited.

Dates: Received: 02 August 2019; Revised: 20 September 2019; 27 September 2019

Keywords: Abeokuta metropolis, Noise, spatial pattern, auditory impairment

There are many factors which cause the environment to be polluted and one of those undesired and unpleasant factors is 'noise' which can negatively impact a the quality of life. Noise in the human environment has become a major threat to the quality of human life; especially children and the infirmed, that are at risk of negative impacts of noise pollution due to their high susceptibility level (Haq et al., 2014). Environmental noise is the aggregate of noise emitted into the ambient environment from sources such as transport, industrial and recreational activities among others. Outdoor noise, also called environmental noise (Jhanwar, 2016) has been attributed to poor urban planning that can give rise to noise pollution. Several factors such as, industrial activities, ceremonies/social events, some household chores, construction activities and transportation systems contribute to noise pollution throughout the city. Also included are human activities such as religious, parties, public functions, musical jamboree, commercial activities, trading, hawking, blowing of siren and town-criers as a form of advertisement, and factory plants operations and constructions. The external sources of noise are the most common intense noise nuisance, which includes aircraft, traffics from busy main roads and from motorways, trains and factories. In urban Nigeria, a huge number of auditory ailments have been linked to human activities (Olokesusi and Olorunfemi, 2006) that generate noise. Going by the study conducted in parts of Ibadan City by Oguntoke et al (2015), a close association has been documented to exist between noise level and childhood auditory impairment cases. The impact of noise is determined not only by the sound level but also the duration and frequency of human exposure. Broadly considered, conductive hearing loss and sensorineural hearing loss are the major types of auditory problems. In conductive deafness, sound-pressure waves never reach the inner ear, most often as a result of a ruptured eardrum or a defect in the ossicles of the middle ear (Bugliarello, et al., 1976). Generally, exposure to constant noise may damage sensitive structures in the ear. Rabinowitz (2000) and Olaosun et al. (2009) reported that noiseinduced hearing loss can result from damaged hair cells of the cochlea in the inner ear due to continuous exposure to recreational and occupational 
noise. The hearing limit of noise in man is given at about $140 \mathrm{~dB}$. Human ears feel tiredness when exposed to over $80 \mathrm{~dB}$ for more than half an hour. This could lead to temporary deafness if the loudness of the noise is at $100 \mathrm{~dB}$ while extremely painful condition accompanies exposure to $140 \mathrm{~dB}$ (Kanr, 2007). Apart from the auditory problems caused by human exposure to noise, non-auditory effects linked to abnormal social behaviour have been attributed to exposure to prolonged and often irregular noise (Evans and Lepore, 1993; Stansfeld and Matheson, 2003). Humans exposed to high noise levels have been shown to suffer from headache, dizziness, nervousness, irritability, loss of sleep, anger, depression, anxiety, distraction, agitation, cardiovascular and gastric disturbances, increased blood cholesterol level and hearing loss (Fields, 1998). Otukong (2002) indicated that human exposure to environmental noise may increase the risks related to personal health, such as nervous frailty, extreme irritability, muscle cramps, stress and anxiety, dizziness, headache and migraine, anger and loss of body balance among others. In order to guard against the harmful effect of noise, several countries have set limits to the level of environmental noise allowed at different times of the day. For instance, the laws of Netherlands do not permit building of houses in areas where 24-hour average noise levels exceed $50 \mathrm{dBA}$. In Great Britain; the Noise Act empowers the local authorities to confiscate any noisy equipment and fine people who create excessive noise at night. In the US, 45 and $55 \mathrm{dBA}$ are set for night and day time while areas labelled as silent zones must not exceed 40 and $50 \mathrm{dBA}$ (Enger and Smith 2002). Although, the regulator of Nigerian environmental affairs set creditable noise limits of 40 and $50 \mathrm{dBA}, 45$ and $55 \mathrm{dBA}$, and 50 and $60 \mathrm{dBA}$ for night and day time in areas demarcated as residential, mixed residential and residential cum industrial zones (NESREA 2009). The fact that these limits are neither well publicized nor enforced, presents a situation of complete disregard for such law. Geographical analysis and mapping of noise intensity in urban centres has not received much attention of acoustic researchers, town planners and policy makers especially in these parts of the world. Geographical Information Systems (GIS), a veritable tool for conducting spatial analysis and mapping is scarcely employed in noise studies in Nigeria. GIS is capable of gathering, weighting, analyzing and presenting spatial and attribute information to facilitate the comprehension and management of environmental pollutions (Alesheikh et al., 2007). The application of this tool for monitoring and forecasting noise pollution patterns has been demonstrated in some developed countries around the globe (Mehdi et al., 2005). The outcomes present areal based analysis and visualization of noise data for environmental performance evaluation and planning purposes, with a view to control noise pollution. Noise mapping is a very efficient noise assessment method in urban areas (Panadya, 2003). An environmental noise map is considered as a veritable tool for improving and preserving the quality of the environment with respect to noise pollution. It can present a comprehensive picture of noise from multiple sources and receivers. Furthermore, the mapping of environmental noise has the potential to enable data to be accessible to the general public in a way that is comprehensible. This could have the effect of raising people's awareness of noise as a pollutant and, thus, creating the climate necessary for the implementation of a noise-reduction program. Environmental soundscapes are specific to areas as a result of their spatio-temporal characteristics since sound varies with time and space (Waugh et al. 2003). Spatial analysis of noise generation portrays noise boundaries using surface distribution thereby identifying risk zones or 'hot spots' within a study area. Realizing the efficacy of noise map, the European Union set a deadline of year 2002 for drawing up the 'noise maps' of big cities in the countries (Bond, 1996). This study is therefore a step in the right direction to provide data for decision making and noise control planning.

\section{MATERIALS AND METHODS}

Description of the Study Area: The Abeokuta metropolis serves as the capital of Ogun State, which is bordered by Lagos, Oyo, Ondo, and Osun States. It is located within the south-western part of Nigeria on Longitude $3.33^{\circ} \mathrm{E}$ and latitude $7.17^{\circ} \mathrm{N}$. Abeokuta is about $103 \mathrm{~km}$ and $79 \mathrm{~km}$ to Lagos and Ibadan respectively. The whole city falls within four Local Government Areas in the State namely: Abeokuta South, Abeokuta North, and parts of Odeda, and Obafemi/Owode Local Government Areas (Figure 1). The city is specifically located within the humid tropical region with a mean annual rainfall of 1090.5 mm (Akanni, 1992). The city covers a geographical area of $1256 \mathrm{Km}^{2}$. It has an estimated population of 888,924 inhabitants in 2012. Due to the fertile soils found in the region, farming is the traditional occupation of the people. However, with the recent industrial development and establishment of various tertiary institutions within the city, other forms of land uses are emerging.

Assessment of Environmental Noise: The Map of Abeokuta metropolis was obtained and gridded to create cells of $1000 \mathrm{~m}^{2}$ using ArcMap 10.1 (Figure 2). The gridded map was overlaid on a high-resolution image so as to identify the locations that fall within 
each of the cells (Niederheiserab, et al., 2018; Oguntoke et al., 2019). These locations were extracted and documented for field survey exercise.

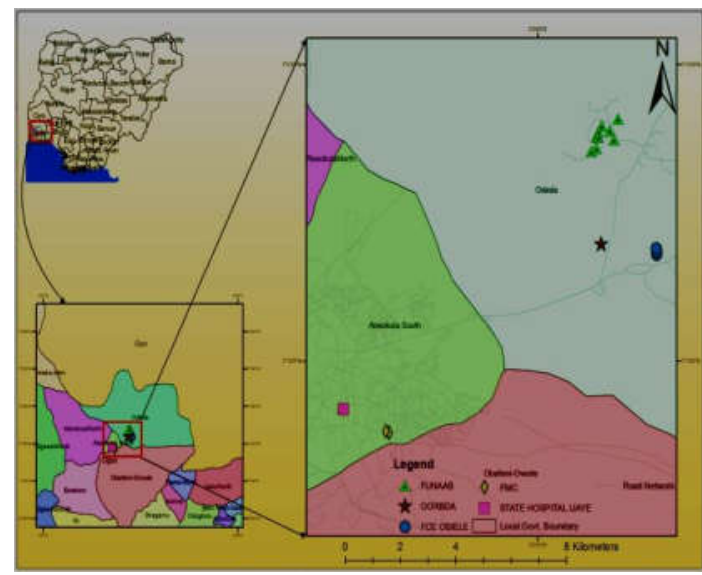

Fig. 1: Map of Ogun State showing the location of Abeokuta municipality

Forty percent of cells (33 of 80 cells) were selected randomly for noise measurement. In each cell, four sampling points were selected. Sampling within the cells was carried out with the aid of noise meter at each sampling point. The spatial attributes (coordinates) of the sampling sites were obtained using the Global Positioning System (Garmin GPS-72H). The noise assessment was carried out in the morning $(7-9 \mathrm{am})$, afternoon (2 - $4 \mathrm{pm})$, and evening (6-8 pm). A calibrated Smart Sensor Digital Sound Level Meter (model AR824) with range 30 - $130 \mathrm{~dB}$ (option $30-$ $110 \mathrm{~dB}$ ) was used to measure noise levels at each site. Measurements were taken with the microphone facing the four (4) cardinal points at each site. It was held at a height of $1.2 \mathrm{~m}$ in the ambient environment. At each point within and around the selected areas, four measurements were taken. The noise meter was set and the "max" button was held to get the maximum noise level at each site. Data were collected for the study was conducted between June and December, 2016.

Collection of Hospital data: Reported cases of auditory ailments were collected from selected Hospitals in Abeokuta (Federal medical Centre, General Hospital Ijaiye, Sacred Hospital Lantoro and Olikoye Ransome-Kuti Hospital Asero). The specific parameters that were collected from the medical records included; age, sex, occupation, date of reporting and the residential area of the patients. While the first three parameters were used to provide demographic information about patients diagnosed with auditory ailments, the last parameter was utilized to depict the spatial pattern of recorded cases.

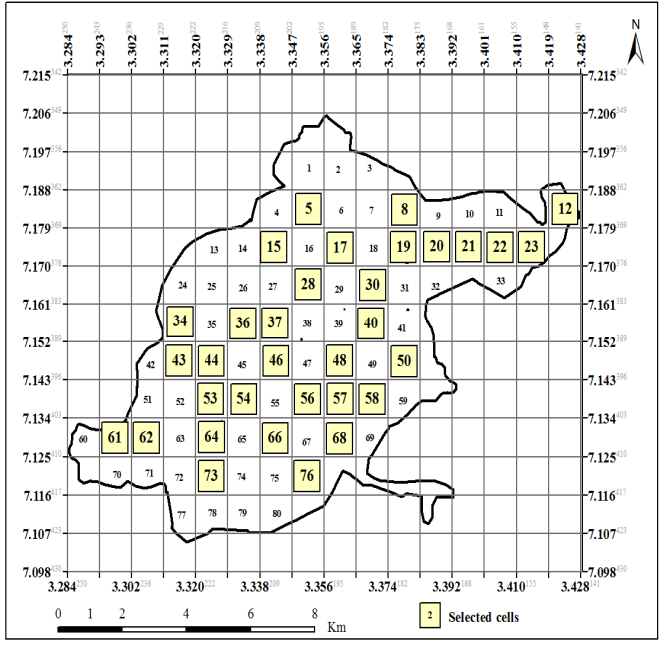

Fig. 2: Division of Abeokuta metropolis into cells (1000 m by $1000 \mathrm{~m})$

GIS Analysis: The geographical coordinates (Longitude and Latitude) of each location were recorded at each point of the selected site where noise levels were monitored. These coordinates were entered into Microsoft Excel spreadsheet and exported into ArcMap 10.1 environment for spatial analysis. Kriging technique in ArcMap software 10.1 was employed to produce noise risk maps for the study area, using mean noise values of the sampled cells. The noise risk ranges are as follows; above 75 (very high), 71-75 (high), 65-70 (moderate) and below 65 dBA (normal) which are designated with different colours (Olaf, 2004; Polash et al., 2016).

Statistical analysis: Data obtained from noise measurement and hospital records were entered into Microsoft Excel spread-sheets and exported into the Statistical Package for Social Sciences (SPSS 20.0) for analysis. Descriptive (frequency-run and percentage) and inferential statistical tools (mean, analysis of variance - ANOVA) and Post Hoc Test - DMRT) were employed to analyze the significant variation in mean noise levels. Furthermore, Pearson's correlation analysis was used to analyze the association between noise levels and cases of auditory ailments in Abeokuta city.

\section{RESULTS AND DISCUSSION}

Spatial Variations in the level of Noise at different times of the Day: In morning hours (7 - 9 am), maximal noise levels were assessed at Kuto (88.2 $\mathrm{dBA})$, Isale-Igbein (76.1 dBA) and Okelowo (75.0 $\mathrm{dBA})$. On the other hand, areas with minimal noise levels included Akin-Olugbade, Saraki, Totoro and Asero (42.4 - 54.2 dBA) as shown in Table 1. 
Table 1: Mean Noise level at Sample Locations in the Morning, Afternoon and Evening

\begin{tabular}{|c|c|c|c|c|}
\hline$\overline{\mathbf{S} / \mathbf{N}}$ & Location & $\begin{array}{l}\text { Mean noise } \\
\text { levels dB (A) }\end{array}$ & $\begin{array}{l}\text { Mean noise } \\
\text { levels dB (A) }\end{array}$ & $\begin{array}{l}\text { Mean noise } \\
\text { levels dB (A) }\end{array}$ \\
\hline 1 & Kugba & $74.0 \pm 7.66^{\mathrm{bc}}$ & $69.8 \pm 10.3^{\mathrm{b}}$ & $75.9 \pm 7.10^{\mathrm{b}}$ \\
\hline 2 & Oke-Aregba/Gbesele & $55.0 \pm 7.17^{\mathrm{hijkl}}$ & $48.1 \pm 8.95^{\mathrm{hij}}$ & $62.3 \pm 7.59^{\text {fghi }}$ \\
\hline 3 & Upright hotel/Kuforiji & $56.5 \pm 9.18^{\mathrm{hijk}}$ & $54.9 \pm 10.1^{\mathrm{jk}}$ & $61.5 \pm 10.2^{\mathrm{ghi}}$ \\
\hline 4 & Quarry/Bella & $57.3 \pm 9.90^{\text {ghij }}$ & $50.0 \pm 7.54^{\mathrm{lmn}}$ & $51.6 \pm 6.99^{\mathrm{m}}$ \\
\hline 5 & Abule-Ojere & $55.8 \pm 6.36^{\mathrm{hijk}}$ & $45.0 \pm 6.72^{\mathrm{n}}$ & $52.8 \pm 9.38^{\mathrm{klm}}$ \\
\hline 6 & Olokemeji street & $61.4 \pm 7.37^{\text {efg }}$ & $64.5 \pm 6.56^{\text {cdef }}$ & $63.6 \pm 7.58^{\text {fgh }}$ \\
\hline 7 & Abule-Ijeun Olukosi & $54.5 \pm 8.60^{\mathrm{klm}}$ & $45.4 \pm 8.46^{\mathrm{n}}$ & $55.7 \pm 7.51^{\mathrm{ijk}}$ \\
\hline 8 & Ake/Itoko & $64.7 \pm 7.29^{\mathrm{de}}$ & $73.0 \pm 5.54^{\mathrm{b}}$ & $63.2 \pm 6.66^{\text {fgh }}$ \\
\hline 9 & Adedotun/Ikija & $67.3 \pm 5.82^{\text {cd }}$ & $57.0 \pm 6.90^{\mathrm{hij}}$ & $68.9 \pm 4.25^{\mathrm{cd}}$ \\
\hline 10 & Totoro/Olowu & $53.1 \pm 5.03^{\mathrm{jkl}}$ & $65.8 \pm 7.09^{\text {bcde }}$ & $67.2 \pm 4.46^{\text {cde }}$ \\
\hline 11 & Sokori/Elemere & $54.8 \pm 5.33^{\mathrm{ijkl}}$ & $69.4 \pm 6.57^{\mathrm{b}}$ & $64.9 \pm 4.24^{\text {defg }}$ \\
\hline 12 & Olomore & $55.7 \pm 10.1^{\mathrm{hijk}}$ & $56.3 \pm 4.42^{\text {ghij }}$ & $57.5 \pm 6.55^{\mathrm{ghi}}$ \\
\hline 13 & Kuto & $88.2 \pm 15.1^{\mathrm{a}}$ & $86.4 \pm 12.5^{\mathrm{a}}$ & $72.4 \pm 14.3^{\mathrm{bc}}$ \\
\hline 14 & Okelowo & $75.0 \pm 8.48^{\mathrm{b}}$ & $75.1 \pm 7.12^{\mathrm{a}}$ & $71.3 \pm 11.2^{\mathrm{bc}}$ \\
\hline 15 & Paragon & $55.6 \pm 7.90^{\mathrm{hijkl}}$ & $46.2 \pm 7.82^{\mathrm{n}}$ & $54.7 \pm 7.58^{\mathrm{klm}}$ \\
\hline 16 & Iyana-mortuary & $55.3 \pm 7.14^{\mathrm{hijkl}}$ & $54.3 \pm 7.90^{\mathrm{jk}}$ & $63.4 \pm 9.69^{\mathrm{efg}}$ \\
\hline 17 & Ibara post office & $71.4 \pm 6.43^{\mathrm{bc}}$ & $67.5 \pm 5.56^{\mathrm{bc}}$ & $66.3 \pm 5.33^{\text {def }}$ \\
\hline 18 & Isale-Igbein & $76.1 \pm 9.77^{\mathrm{b}}$ & $64.9 \pm 8.25^{\text {cde }}$ & $62.8 \pm 7.08^{\text {fgh }}$ \\
\hline 19 & Onikoko/Adigbe & $63.4 \pm 5.52^{\mathrm{jkl}}$ & $67.1 \pm 9.64^{\text {bcd }}$ & $61.3 \pm 7.29^{\text {ghi }}$ \\
\hline 20 & Saraki/Obada road & $52.4 \pm 7.37^{\mathrm{kl}}$ & $52.3 \pm 7.39^{\mathrm{klm}}$ & $66.4 \pm 5.01^{\text {def }}$ \\
\hline 21 & Asero & $54.2 \pm 6.65^{\mathrm{jkl}}$ & $47.7 \pm 6.10^{\mathrm{n}}$ & $64.1 \pm 8.99^{\text {fgh }}$ \\
\hline 22 & Olokuta-Kemta & $63.4 \pm 7.94^{\text {def }}$ & $64.7 \pm 10.3^{\text {cdef }}$ & $52.9 \pm 8.79^{\mathrm{lm}}$ \\
\hline 23 & Leme/Sam Ewang & $54.8 \pm 6.54^{\mathrm{ijkl}}$ & $45.3 \pm 8.48^{\mathrm{n}}$ & $51.0 \pm 6.55^{\mathrm{kl}}$ \\
\hline 24 & Aregbe & $59.1 \pm 6.82^{\text {ghi }}$ & $51.4 \pm 7.68^{\mathrm{klm}}$ & $53.9 \pm 9.13^{\mathrm{klm}}$ \\
\hline 25 & Akin-Olugbade & $42.4 \pm 4.14^{\mathrm{jk}}$ & $54.0 \pm 6.76^{\mathrm{ij}}$ & $51.8 \pm 7.04^{\mathrm{lm}}$ \\
\hline 26 & Shomorin & $59.6 \pm 6.69^{\mathrm{fgh}}$ & $68.6 \pm 5.55^{\mathrm{bc}}$ & $54.7 \pm 8.66^{\mathrm{ijk}}$ \\
\hline 27 & Alogi & $64.3 \pm 6.18^{\mathrm{de}}$ & $70.0 \pm 7.88^{\mathrm{b}}$ & $60.5 \pm 11.7^{\text {ghij }}$ \\
\hline 28 & Fajol & $71.6 \pm 4.90^{\mathrm{bc}}$ & $52.7 \pm 6.35^{\mathrm{lm}}$ & $61.2 \pm 9.16^{\text {ghij }}$ \\
\hline 29 & Elite & $55.6 \pm 8.96^{\mathrm{hijk}}$ & $61.6 \pm 8.09^{\text {cdef }}$ & $65.0 \pm 7.94^{\mathrm{ghi}}$ \\
\hline 30 & FMC & $56.5 \pm 4.48^{\text {hijk }}$ & $62.2 \pm 7.22^{\text {efghi }}$ & $61.4 \pm 8.27^{\text {ghi }}$ \\
\hline 31 & Abiola way & $65.2 \pm 8.09^{\text {def }}$ & $75.2 \pm 4.90^{\mathrm{a}}$ & $73.7 \pm 8.91^{\mathrm{b}}$ \\
\hline 32 & Sapon & $70.4 \pm 5.35^{\mathrm{bc}}$ & $77.0 \pm 5.20^{\mathrm{a}}$ & $84.4 \pm 5.19^{\mathrm{a}}$ \\
\hline \multirow[t]{2}{*}{33} & Camp & $59.6 \pm 7.16^{\text {fgh }}$ & $56.2 \pm 9.45^{\mathrm{jk}}$ & $63.2 \pm 6.44^{\mathrm{fgh}}$ \\
\hline & *Permissible limit & $55 \mathrm{~dB}(\mathrm{~A})$ & $55 \mathrm{~dB}(\mathrm{~A})$ & $45-55 \mathrm{~dB}(\mathrm{~A})$ \\
\hline
\end{tabular}

Table 2: Occurrence of Auditory ailments among age groups in Abeokuta

\begin{tabular}{llllllllll}
\hline Auditory cases & $0-10$ & $11-20$ & $21-30$ & $31-40$ & $41-50$ & $51-60$ & $>60$ & Total & $\%$ \\
\hline Delayed speech & 16 & 1 & 0 & 1 & 0 & 0 & 0 & 18 & 2.7 \\
Ear ache & 14 & 5 & 9 & 6 & 2 & 5 & 3 & 44 & 6.6 \\
Ear discharge & 25 & 3 & 1 & 1 & 0 & 0 & 0 & 30 & 4.5 \\
Foreign object & 9 & 2 & 1 & 1 & 3 & 1 & 0 & 17 & 2.6 \\
Impaired hearing & 24 & 33 & 38 & 12 & 21 & 22 & 21 & 172 & 25.8 \\
Wax impaction & 27 & 11 & 5 & 5 & 2 & 3 & 9 & 62 & 9.3 \\
Otitis/Otomycosis & 36 & 12 & 16 & 13 & 11 & 5 & 7 & 100 & 15.0 \\
Partial deafness & 6 & 3 & 2 & 6 & 5 & 0 & 2 & 24 & 3.6 \\
Sensorineural hearing loss & 9 & 9 & 6 & 6 & 3 & 2 & 5 & 40 & 6.0 \\
Speech impairment & 15 & 5 & 1 & 2 & 2 & 0 & 0 & 25 & 3.8 \\
Tinnitus & 4 & 7 & 14 & 19 & 24 & 31 & 10 & 109 & 16.4 \\
Others & 1 & 1 & 6 & 7 & 3 & 4 & 3 & 25 & 3.8 \\
Total & 186 & 92 & 100 & 79 & 76 & 73 & 60 & 666 & 100 \\
\% & 28.0 & 13.8 & 15.0 & 11.9 & 11.4 & 11.0 & 9.0 & 100 & 100 \\
\hline
\end{tabular}

Noise levels in the afternoon $(2-4 \mathrm{pm})$ showed that Kuto (86.4 dBA), Sapon (77.0 dBA), Abiola way (75.2 dBA), Okelowo (75.1 dBA) and Ake (73.0 dBA) had the highest values. Areas with low noise levels in the afternoon include Leme, Ijeun-Lukosi, Asero, OkeAregba, Quarry, Aregbe, Fajol and Iyana-mortuary (45.3 -54.3 dBA).

Areas such as Sapon (84.4 dBA), Kugba (75.9 dBA), Abiola way (73.7 dBA), Kuto $(72.4 \mathrm{dBA})$ and
Okelowo (71.3 dBA) had high noise levels in the evening (6-8 pm). On the other hand, low noise levels were assessed at Leme, Quarry, Akin-Olugbade, Abule-Ojere and Kemta (51.0 -52.9 dBA). There was significant varaition in the levels of noise at the various locations and different times of the day $(\mathrm{P}<0.05)$. Apart from Ake and Kugba that had high noise levels in the afternoon and evening, Kuto, Okelewo, Sapon and Abiola-way had high noise levels 
throughout the day. Generally, $60.6 \%, 61 \%$ and $72.7 \%$ of the areas assessed in the morning, afternoon and evening had noise levels that exceeded the permissible limits set by the WHO and NESREA. By implication, the residents living in these areas are exposed to noise that put them at risk of suffering from hearing impairments and other non-auditory problems. The high noise level assessed at Kuto, Isale-Igbein and Okelowo at morning hours may be due to high volume of vehicular traffic as workers rush to reach their places of work. Also, the concentration of commercial activities and presence of motor parks in the first two areas could contribute to the noise levels. The high noise level measured at Kuto, Sapon, Abiola way, Okelowo and Ake at afternoon hours can be attributed to the concentration of shops, markets and high volume of vehicular traffic in the neighbourhood. Also, the contribution of noise from music players, use of electric generators for power supply and use of loudspeakers by hawkers of different kinds of goods are cupable. The high noise level assessed at Sapon, Kugba, Abiola way, Kuto and Okelowo at evening hours could be attributed to heavy vehicular traffic as most workers would be returning from the day's work. In addition, noise emitted from relaxation centers, sounds from music players in the neighbourhoods, use of electricity generating sets, and food grinding machines contributed to the background noise in the environment. On the other hand, areas with low noise levels such as Akin-Olugbade, Saraki, Totoro and Asero are largely residential areas with minimal commercial activities. Moreover, some of these residential areas are newly developing with sparse population; such include Asero housing Estate and government-reserved areas. In agreement with some of the noise sources identified by this study, Egunjobi (1983) indicated similar sources in Ibadan city. Authors have indicated that living in acoustic zones where the equivalent sound level is higher than 65 $\mathrm{dBA}$ put an urban population in a high risk status for numerous subjective effects of noise (Alberola et al. 2005). Environmental noise level for preserving human health in residential areas is not expected to exceed 45 and $50 \mathrm{~dB}$ (A) during night time (WHO, 1995).

Table 3: Occurrence of cases of Auditory Ailments among residential areas in Abeokuta city

\begin{tabular}{|c|c|c|c|c|c|c|c|c|c|c|c|c|c|c|c|c|c|}
\hline Auditory Ailments & 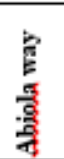 & $\frac{\text { 点 }}{\text { 尊 }}$ & $\frac{y}{4}$ & $\frac{\mathrm{g}}{3}$ & 冒 & 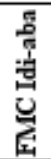 & 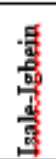 & 疍 & 营 & $\frac{8}{3}$ & $\begin{array}{l}\frac{\pi}{5} \\
\frac{3}{3} \\
\frac{3}{2}\end{array}$ & 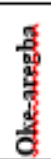 & $\frac{\frac{8}{3}}{\frac{8}{8}}$ & 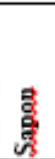 & 兽 & 푱 & 앙 \\
\hline Delayed speech & 0 & 3 & 2 & 0 & 0 & 1 & 0 & 0 & 2 & 3 & 5 & 0 & 0 & 1 & 0 & 18 & 2.7 \\
\hline Ear ache & 4 & 3 & 1 & 2 & 4 & 0 & 0 & 1 & 3 & 8 & 9 & 0 & 1 & 7 & 1 & 44 & 6.6 \\
\hline Ear discharge & 3 & 1 & 0 & 2 & 2 & 0 & 0 & 3 & 2 & 3 & 3 & 2 & 3 & 5 & 1 & 30 & 4.5 \\
\hline Foreign object in ear & 1 & 2 & 0 & 1 & 0 & 1 & 1 & 1 & 1 & 2 & 3 & 0 & 0 & 3 & 1 & 17 & 2.6 \\
\hline Impaired hearing & 13 & 10 & 2 & 10 & 13 & 10 & 4 & 6 & 20 & 16 & 21 & 2 & 11 & 27 & 6 & 172 & 25.8 \\
\hline Wax impaction & 8 & 3 & 1 & 6 & 3 & 2 & 1 & 1 & 2 & 6 & 15 & 1 & 5 & 8 & 1 & 62 & 9.3 \\
\hline Otitis/Otomycosis. & 13 & 6 & 1 & 4 & 6 & 5 & 0 & 2 & 8 & 8 & 18 & 3 & 6 & 15 & 3 & 100 & 15.0 \\
\hline Partial deafness & 2 & 1 & 0 & 2 & 2 & 0 & 0 & 1 & 1 & 4 & 8 & 0 & 0 & 2 & 1 & 24 & 3.6 \\
\hline Sensoxineuxal hearing loss & 3 & 4 & 0 & 2 & 2 & 0 & 1 & 0 & 5 & 5 & 8 & 1 & 4 & 4 & 1 & 40 & 6.0 \\
\hline Speech impairment & 4 & 1 & 0 & 0 & 2 & 2 & 0 & 5 & 1 & 4 & 4 & 0 & 0 & 5 & 0 & 25 & 3.8 \\
\hline Tinnitus & 17 & 7 & 5 & 6 & 8 & 7 & 0 & 3 & 9 & 20 & 22 & 0 & 2 & 10 & 0 & 109 & 16.4 \\
\hline Others & 4 & 2 & 0 & 1 & 4 & 3 & 1 & 0 & 0 & 2 & 2 & 0 & 0 & 4 & 0 & 25 & 3.8 \\
\hline Total & 72 & 43 & 12 & 36 & 46 & 31 & 8 & 23 & 54 & 74 & 119 & 9 & 33 & 91 & 15 & 666 & 100.0 \\
\hline & 11.0 & 6.5 & 1.8 & 5.4 & 6.9 & 4.7 & 1.2 & 3.5 & 8.1 & 11.1 & 17.9 & 1.4 & 5.0 & 14.0 & 2.3 & 100.0 & \\
\hline
\end{tabular}

Table 4: Coefficients of correlation between auditory ailments and noise levels

\begin{tabular}{lllll}
\hline Auditory ailments & $\begin{array}{l}\text { Morning } \\
\text { noise levels }\end{array}$ & $\begin{array}{l}\text { Afternoon } \\
\text { noise levels }\end{array}$ & $\begin{array}{l}\text { Evening } \\
\text { noise levels }\end{array}$ & $\begin{array}{l}\text { Mean daily } \\
\text { levels }\end{array}$ \\
\hline Delayed speech & 0.07 & 0.10 & -0.09 & 0.05 \\
Ear ache & $0.39^{*}$ & 0.14 & 0.03 & 0.21 \\
Ear discharge & 0.13 & 0.08 & 0.13 & 0.12 \\
Foreign object in ear & $0.38^{*}$ & 0.24 & 0.11 & 0.29 \\
Impaired hearing & 0.19 & 0.07 & 0.12 & 0.13 \\
Hearing loss & 0.12 & 0.09 & -0.02 & 0.02 \\
Others & 0.02 & 0.01 & 0.05 & 0.02 \\
Otitis/Otomycosis & 0.24 & 0.17 & 0.08 & 0.18 \\
Partial deafness & $0.38^{*}$ & 0.19 & -0.07 & 0.20 \\
Sensorineural hearing loss & 0.27 & 0.17 & 0.11 & 0.20 \\
Speech impairment & 0.03 & -0.01 & -0.01 & -0.07 \\
Tinnitus & 0.22 & 0.24 & 0.11 & 0.22 \\
Wax impaction & 0.26 & 0.29 & 0.12 & 0.26 \\
\hline
\end{tabular}


Spatial Prediction of Noise Risk in Abeokuta Metropolis: The risk maps of Abeokuta metropolis revealed areas with very high, high, moderate and normal risk of noise pollution based on noise levels assessed in the morning, afternoon, evening and the mean daily level which is a composite of the three periods (Figure $2-5$ ). The risk map shows that the noise level in Abeokuta metropolis is predominantly normal and moderate in the morning except in the core parts of the city (Fig. 3). The major areas depicted with very high noise risk in the morning were Okelewo, Kuto, Isale-Igbein and Kugba. Places such as Ibara, Sapon, Ikija Alogi and Fajol are predicted as high noise risk areas. The noise level in the areas with moderate noise risk can be attributed to the trickledown effect of noise from the high risk zones which could filter to neighbouring areas. Fig. 5 revealed that only Sapon and its neighbourhood had very high noise risk. Places such as Abiola-way, Kugba, Kuto and Okelewo are predicted to have high noise risk. Remaining areas in the city are predicted to have moderate noise risk. Although the areal spread of very high noise risk reduced in the evening, high and moderate noise risk areas increased compare to afternoon and morning. With the concentric pattern of noise risks in the metropolis, noise risks pattern can be attributed to the trickledown or diffusion effect of noise from the very high zone to high zone, and from high zone to moderate zone in the city. At morning, afternoon and evening the areas that are predicted to be 'hotspot' of noise pollution in this study are hazardous and unsafe for humans. Although anybody could be adversely affected by noise pollution, the groups that are particularly vulnerable include infants, children, those with mental or physically illness, and the aged people, that are more sensitive to acoustic disturbance (Brookhouser, 1996; Stansfeld and Matheson, 2003). Individuals residing in most of the high risk location are at risk of noise related ailments like temporary or permanent deafness, high blood pressure, headache, annoyance, poor psychological well-being and reduced quality of life (Dai et al., 2005). The risk maps for morning, afternoon and evening in this study is similar to findings of Oloruntoba et al. (2012) and Yesufu et al. (2013) in Ibadan city, and Akintuyi et al (2014) in Bariga area of Lagos state, Nigeria. They identified areas referred to as noisy and low noise in their studies. Studies in parts of Japan, Spain, Brazil, Turkey, Egypt and India have also indicated spatial variations in noise risk (Garcia and Garrigues, 1998; Zannin et al. 2002; Ali and Tamura, 2003; Dai et al., 2005; Ahamad et al., 2006). Among the eleven categories of auditory ailments, impaired hearing has the highest percentage $(25.8 \%)$, followed by tinnitus $(16.4 \%)$ and otitis $(15.0 \%)$ for all the age groups as shown in Table 2.
The lowest number of cases were from partial deafness (3.6\%), delayed speech $(2.7 \%)$ and foreign objects in ear $(2.6 \%)$. Generally, children below the age of 11 years had the highest cases of hearing problems ( $27.9 \%)$, followed by $15 \%$ cases recorded by age 21 30 years and $11-20$ years (13.8\%). Specifically, ages 21-30 years reported more cases of impaired hearing followed by 11-20 years and 51-60 years. The low cases of sensorineural impairment observed among children less than 10 years concurs with the finding of Oguntoke et al. (2015) in Ibadan city, Nigeria. Going by the distribution of the categories of auditory ailments in the specific areas of the metropolis (Table 3 ), the highest number of cases were from Obantoko (17.9\%), Sapon (14.0\%), Kuto (11.1\%), Abiola-way $(11.0 \%)$ and Kugba $(8.1 \%)$ areas. Many of the remaining residential areas reported fewer number of cases (below 7\%) within the study period. Specifically, Sapon dominated cases of impaired hearing followed by Obantoko and Kugba. Also, Obantoko recorded highest cases of tinnitus, followed by Kuto and Abiola-way. Otitis cases were also high at Obantoko, Sapon and Abiola-way. The number of cases recorded in these locations could be attributed in part to prevalence of high noise levels in the area. Apart from the possible influence of large population in some of these areas and the fact the residents are relatively more educated, which might contribute to the number of cases reported at Hospitals, noise emitting activities such as welding, block making and artisan shops are quite many in these residential areas. Human exposure to noise from small scale industries located in parts of these areas are capable predisposing the residents to risks of noise pollution (Oguntoke et al., 2015).

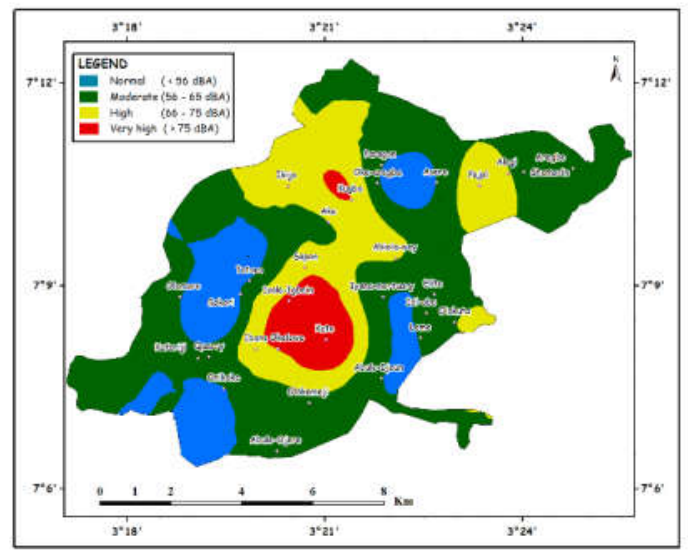

Fig. 3: Spatial prediction of Noise risk in Abeokuta city (morning) 


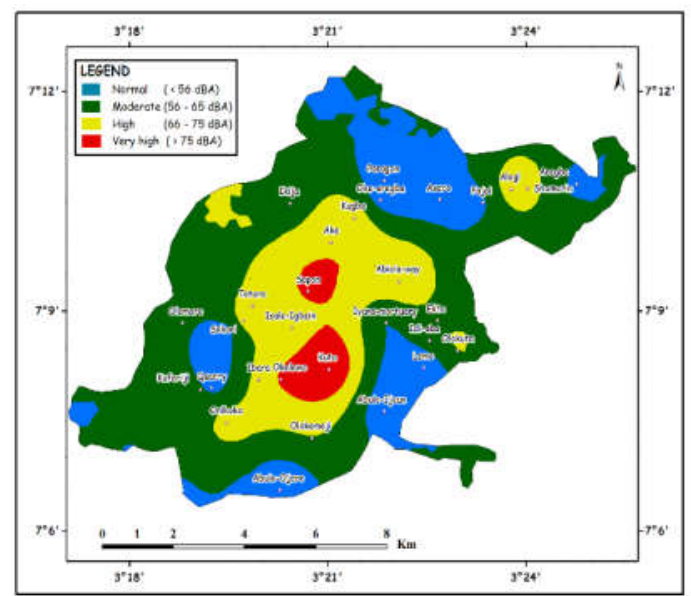

Fig. 4: Spatial prediction of Noise risk in Abeokuta city (afternoon)

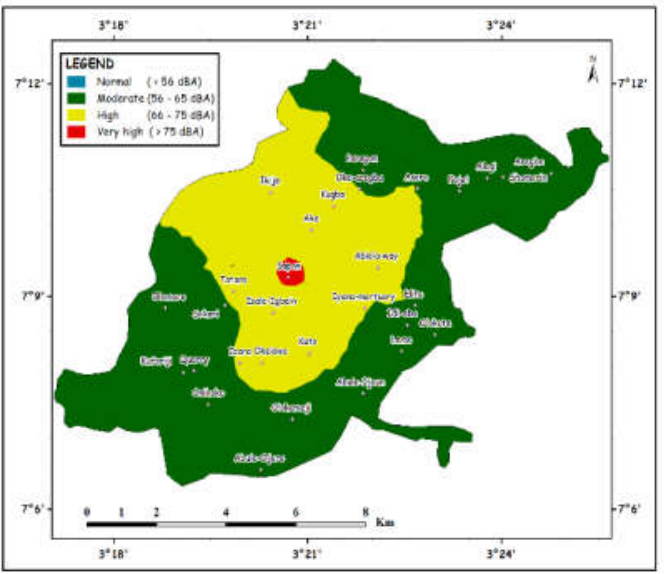

Fig. 5: Spatial prediction of Noise risk in Abeokuta city (evening)

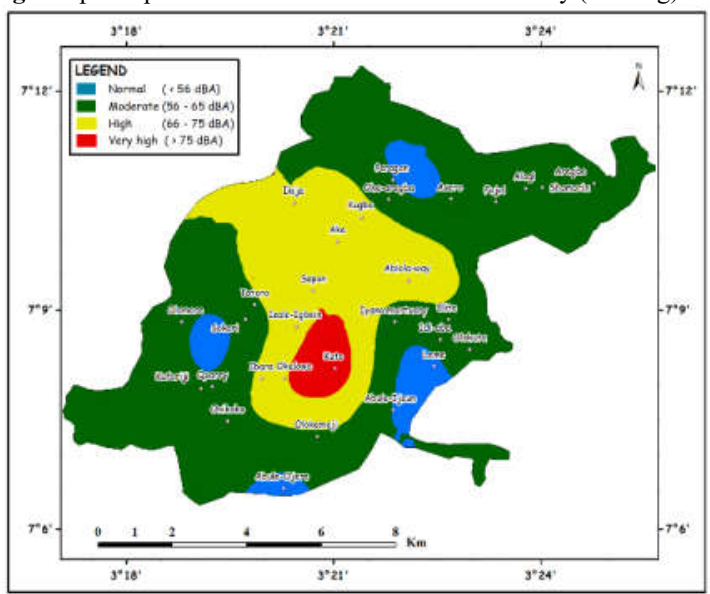

Fig. 6: Spatial prediction of Noise risk in Abeokuta city (composite)

Correlation between reported cases of auditory ailments and Noise levels: The correlation analysis of noise levels and occurrence of hearing impairment cases showed significant positive correlation (Table 3). Specifically, positive correlation was found between cases of hearing impairment and noise level in the morning hours $(\mathrm{r}=0.38-0.39)$. Moreover, ear ache, foreign object in ear and partial deafness show significant positive association with noise level in the morning $(\mathrm{r}=0.39,0.38$ and 0.38 respectively $p<0.05)$. By implication, areas that had high noise levels in the morning equally recorded more cases of auditory ailments. This analysis shows that noise levels in each area contribute to morbidity of auditory ailments. The positive association between noise levels and occurrence of hearing impairment has been observed in previous studies (Amedofu et al., 2005; Smith et al., 2005; Oguntoke et al., 2015). Apart from the impact of noise exposure in the causation of auditory ailments, other factors such as infections are also implicated (Hear-it.org 2011). This biological factor was also adduced as a cofounding and spatially cooccurring factor in the concentration of childhood hearing problems in low and medium income residential areas of Ibadan city in Nigeria (Oguntoke et al., 2015).

Conclusion: Abeokuta metropolis is largely noisy as more than halve of the sampled areas recorded high noise levels $(>55 \mathrm{~dB})$ at the different periods of the day. About a quarter of the diagnosed cases of auditory ailments among the areas were associated with the prevailing environmental noise levels. There is therefore the need for Community Development Associations (CDAs) and government agencies to sensitize the residents and put firm control on the level of noise generated by activities found culpable in the high noise risk neighbourhoods.

\section{REFERENCES}

Ahamad, J; Abbas, A; Reem, S (2006). Evaluation of traffic noise pollution in Amman, Jordan. Environ. Monitor. Assess. 120: 499-525

Akanni, CO (1992). Aspect of climate. In: Onakomaya, SO; Oyesiku, K; Jegede, J (Eds) Ogun State in maps, Rex Charles Publication, Ibadan, 207pp

Akintuyi, AO; Raji, SA; Adewuni, D; Wunude, EO (2014). Gis-Based assessment and mapping of noise pollution in Bariga area of Lagos State, Nigeria. Sokoto J. Social Sci. 4(1): $154-167$

Alberola, J; Flindell, H; Bullmore, J (2005). Variability in road traffic noise levels. European Commission, Environmental Noise Directive 2002/49/EC, Off. J. Euro. Commun. 189: 12-25. 
Alesheikh, AA; Sadeghi, N; Fard, F (2007). Design and implementation of a Knowledge Based System to Improve Maximum Likelihood Classification Accuracy. Canadian J. Remote Sensing 33(6): 459467.

Ali, SA; Tamura, A (2003). Road traffic noise levels. Restrictions and annoyance in greater Cario, Egypt. Appl. Acoust. 64(8): 815-823.

Amedofu, GK; Ocansey, G; Antwi, BB (2005). Characteristics of hearing-impairment among patients in Ghana. Afri. J. of Heal. Sci. 12:87-93.

Bond, M (1996). Plague by noise. New Scientist 649 (16): 14-15.

Brookhouser, PE (1996). Sensorineural hearing loss in children. Pediatric Clinic N. Amer. 43: 11951216.

Bugliarello, G; Alexandre, A; Barnes, J; Wakstein, C (1976). The Impact of Noise Pollution: A SocioTechnological Introduction, Pergamon press, NY.

Dai, L; Cao, J; Fan, L; Mobed, N (2005). Traffic noise evaluation and analysis in residential areas of Regina. J. Environ. Informat. 5(1): 17-25.

Egunjobi, L (1983). Perception of Environmental Problems, Pilot Study centred on the City of Ibadan, Research Report, NISER, Ibadan.

Enger, ED; Smith, BF (2002). Environmental Science: A study of Interrelationship (8th edition) McGraw-Hill Higher Education, New York.

Evans, GW; Lepore, SJ (1993). Non-auditory effects of noise on children. Children's Environ. 10: 31-51

Fields, JM (1998). Reactions to environmental noise in an ambient noise context in residential areas. $J$. Acoust. Soc. Amer. 104: 2245-2260.

Garcia, G; Garrigues, J (1998). 24-hour Continuous Sound-level Measurement Conducted in Spanish Urban Areas. Noise Cont. Eng. J. 46 (4):159-166.

Haq, I; Hussain, T; Farooq, H; Ahmad, MR (2014). Evaluation of the traffic noise pollution at some busiest sites of Faisalabad City, Pakistan. Acad. Res. Inter. 5: 23-26.

Hear-it.org (2011). Hearing. Available from http:// www.hear-it.org (accessed May 1, 2011).
Jhanwar, D (2016). Noise Pollution: A Review. J. Environ. Pollution Human Health. 4(3): 72-77.

Kanr, K (2007). Noise pollution a serious environmental threat to health. Law and its Control. Fifth International Conference on International Environmental Law, organized by the Indian Society of International Law at New Delhi, India, 81pp.

Mehdi, MR; Arsalan, MH (2005). Uncertainties in GIS modeling for noise patterns recognition on meso-scale Managing uncertainty in noise measurement and prediction. Le Mans, France: INCE/Europe. 1-10pp.

NESREA (2009). National Environmental Noise Standards and Control Regulations, Federal Republic of Nigeria Official Gazette, FGP 104/102009/1,000 (OL 60), National Environmental Standards and Regulations Enforcement Agency, Federal Government Printer, Abuja.

Niederheiserab, R; Rutzingerab, M; Bremerab, M; Wichmann,V (2018). Dense image matching of terrestrial imagery for deriving high-resolution topographic properties of vegetation locations in alpine terrain. Int. J. Appl. Earth Observ. Geoinf. 66: 146-158.

Oguntoke, O; Olatinwo, M; Taiwo, OJ (2015). Spatial association between environmental noise levels and occurrence of children hearing impairments in Ibadan Metropolis, Nigeria. Appl. Environ. Res. 37(3): $79-89$.

Oguntoke, O; Amaefuna, BA; Nwosisi, MC; Oyedepo, SA; Oyatogun, MO (2019). Quantification of Biodegradable Household Solid Waste for Biogas Production and the Challenges of waste sorting in Abeokuta Metropolis, Nigeria. Int. J. Energ Water Res. DOI 10.1007/s42108-01900033-9.

Olaf, B (2004). Exploratory disease mapping: kriging the spatial risk function from regional count data. Int. J. Health Geog. 3(18): 3-18.

Olaosun, AO; Ogundiran, O; Tobih, JE (2009). Health hazards of noise: A Review Article. Res. J. Med. Sci. 3(3):115-122.

Olokesusi, F; Olorunfemi, F (2006). Noise Pollution in Nigeria. In: Ivbijaro, MF; Akintola, AF; Okechukwu, RU (Eds). Sustainable Environmental 
Management in Nigeria, Mattivi Production, Ibadan, pp 295-300.

Oloruntoba, EO; Ademola, RA; Sridhar, MKC; Omokhodion, FO; Ana, GREE; Agbola, SA; Alabi, RT (2012). Urban environmental noise pollution and perceived health effects in Ibadan. Afri. J. Biomed. Res. 15: 77-84.

Otukong, ITO (2002). Environmental pollution and emerging health hazard: The Nigerian scenario. $J$. Gen. Pract. 7(1): 3-4.

Panadya, GH (2003). Assessment of traffic noise and its impact on community Inter. J. Environ. Studies. 60(6): 595-602.

Polash B; Mrinal, KG; Ratika, P (2016). GIS based spatial noise impact analysis (SNIA) of the broadening of national highway in Sikkim Himalayas: a case study. AIMS Env. Sci. 3(4): 714738.

Rabinowitz, P (2000). Noise-Induced hearing loss. Amer. Family Physi. 61: 2749-2760.

Smith RJH; Bale, JFJ; White, KR (2005). Sensorineural hearing loss in children. Lancet 365 : 879-890.
Stansfeld, AS; Matheson, PM (2003). Noise pollution: non-auditory effects on health. Bri. Med. Bull. 68: 243-257.

Waugh, D; Durucan, S; Korre, A; Hetherington, O; O'Reilly, B (2003). Environmental Quality Objectives -Noise in Quiet Areas Synthesis Report, Environmental Protection Agency, Ireland.

WHO (1995). Guideline for Community Noise. In: Birgitta, B; Thomas, L; Dietrich, HS (Editors), WHO, Geneva. Available from http//:www.bvsde.paho.org/bvsci/i/fulltext/noise/ noise.pdf (accessed Feb 24 2013)

WHO (2001). WHO Guidelines on Community Noise (Ed.) Dietrich Schwela. TRB Session 391, WHO, Geneva.

Yesufu, AL; Ana, GREE; Yawei, Z; Umar, OZ (2013). Work Environment Noise Levels and Risk Locations in two Selected Commercial Areas in Ibadan, Nigeria. Global J. Med. Res. Inter. 13(16): 1.

Zannin, PHT; Diniz, FB; Barbosa WA (2002). Environmental noise pollution in the city of Curitiba. Brazil. Appl. Acoust. 63: 351-358. 